\title{
ANALISIS KEMAMPUAN BERARGUMENTASI ILMIAH MATERI IKATAN KIMIA PESERTA DIDIK SMA, MAN, DAN PERGURUAN TINGGI TINGKAT I
}

\author{
Wiwit Zahrotul Wahdan a, Oktavia Sulistina ${ }^{\mathrm{b}}$, dan Dedek Sukarianingsih ${ }^{\mathrm{c}}$ \\ a,b,cJurusan Kimia FMIPA Universitas Negeri Malang
}

\begin{abstract}
Abstrak - Penelitian ini bertujuan untuk mendeskripsikan dan mengetahui perbedaan kemampuan berargumentasi ilmiah materi ikatan kimia peserta didik kelas X MIA SMA Negeri 1 Lawang, X MIA MA Negeri 1 Malang, dan mahasiswa Universitas Negeri Malang (UM) Prodi Pendidikan Kimia semester dua angkatan 2016. Penelitian ini menggunakan rancangan penelitian deskriptif dengan pendekatan kualitatif. Subyek penelitian ini adalah peserta didik kelas X MIA 1 SMA Negeri 1 Lawang sebanyak 32 peserta didik, X MIA 3 MAN 1 Malang sebanyak 32 peserta didik, dan UM Prodi Pendidikan Kimia Offering A semester dua angkatan 2016 sebanyak 31 mahasiswa. Instrumen penelitian berupa 3 butir soal esai kemampuan berargumentasi dan pedoman wawancara peserta didik. Hasil penelitian menunjukkan bahwa tidak ada perbedaan kemampuan berargumentasi ilmiah materi ikatan kimia antara SMA Negeri 1 Lawang dengan MA Negeri 1 Malang, SMA Negeri 1 Lawang dengan UM Prodi Pendidikan Kimia semester dua angkatan 2016, dan ada perbedaan antara MA Negeri 1 Malang dengan UM Prodi Pendidikan Kimia semester dua angkatan 2016. Seluruh jenjang pendidikan tersebut didominasi dengan level 2a. Level 2a dengan persentase tertinggi yaitu mahasiswa UM Prodi Pendidikan Kimia semester dua angkatan 2016 sebesar 53,76\% diikuti peserta didik SMA Negeri 1 Lawang sebesar 49,31\% dan MA Negeri 1 Malang sebesar $47,91 \%$. Faktor-faktor yang mempengaruhi kemampuan berargumentasi ilmiah peserta didik adalah pemahaman peserta didik terhadap materi ikatan kimia dan keterlibatan peserta didik dalam kegiatan argumentasi selama proses pembelajaran.
\end{abstract}

\section{Kata kunci: argumentasi ilmiah, ikatan kimia}

\begin{abstract}
The purpose of this research was to describe and to find differences of ability to argue scientifically chemical bonding of students in 10th grade MIA SMA Negeri 1 Lawang, 10th grade MIA MA Negeri 1 Malang, and second semester (2016) of Chemistry Department State University of Malang. This research used a descriptive qualitative design. The subjects of this research were students 10th grade MIA 1 SMA Negeri 1 Lawang with 32 students, 10th grade MIA 3 MAN 1 Malang with 32 students, and second semester (2016) of Chemistry Department State University of Malang with 31 students. Instrument of this research was 3 essays of ability to argue and interview guidance of students. The results showed there are no differences in the ability of scientific argumentation of student between SMA Negeri 1 Lawang with MA Negeri 1 Malang, SMA Negeri 1 Lawang with second semester (2016) Chemistry Department State University of Malang, and be found difference between MA Negeri 1 Malang with second semester (2016) Chemistry Department State University of Malang in chemical bonding. All of education levels dominated by 2a level. The highest percentage in this level is students second semester (2016) of Chemistry Department State University of Malang was 53,76\%, was followed by students SMA Negeri 1 Lawang and MA
\end{abstract}


Negeri 1 Malang were 49,31\% and 47,91\% respectively. Factors that influence of ability to argue scientifically of student are the understanding of the chemical bonding material and the involvement of student in the argumentation activities during the learning process.

Keywords: scientific argumentation, chemical bonding

\section{PENDAHULUAN}

Ilmu kimia merupakan salah satu cabang dari Ilmu Pengetahuan Alam (IPA) yang berkaitan dengan sifat-sifat zat, struktur zat, perubahan zat, hukum-hukum dan prinsipprinsip yang menggambarkan perubahan zat, serta konsep-konsep dan teori-teori yang menjelaskan terjadinya perubahan zat (Effendy, 2016:1). Kajian ilmu kimia meliputi struktur materi, komposisi, sifat, perubahannya serta energi yang terlibat dalam perubahan tersebut (Solfarina, 2012). Tujuan mempelajari kimia adalah agar bisa lebih memahami dasar-dasar konseptual yang ada dalam ilmu kimia dan dapat mengaplikasikan konsep-konsep tersebut untuk menyelesaikan permasalahan yang diberikan (Holme, Luxford, dan Brandriet, 2015). Peserta didik yang tidak bisa memahami dasar-dasar konseptual kimia, akan mengalami kesulitan dalam belajar kimia. Menurut Faika dan Side (2011) kesulitan belajar merupakan suatu kondisi yang dialami peserta didik yang ditandai dengan adanya hambatan-hambatan tertentu yang menyebabkan tidak tercapainya tujuan belajar. Ketidaktercapainya tujuan belajar yang dialami oleh peserta didik dapat mengakibatkan prestasi belajarnya rendah.

Kesulitan yang dialami peserta didik dalam memahami konsep dapat dipengaruhi oleh beberapa faktor, yaitu kurangnya pendukung dalam penguasaan konsep, proses pembelajaran, dan faktor lingkungan peserta didik (Faika dan Side, 2011), yang berdampak pada pemahaman konsep peserta didik. Pratiwi (2016:4) menyatakan bahwa rendahnya pemahaman peserta didik terhadap konsep-konsep kimia akan mempengaruhi cara berpikir peserta didik dalam menyelesaikan masalah-masalah yang muncul akibat perkembangan ilmu pengetahuan dan teknologi. Peserta didik, sebagai bagian dari masyarakat global tidak hanya dituntut untuk memahami konsep-konsep sains, namun juga berperan dalam diskusi adalah kemampuan berargumentasi ilmiah. Menurut Aydeniz dan Ozdilek diskusi sains (Kuhn, 2010). Salah satu kemampuan yang dibutuhkan dalam proses (2015) belajar ilmu pengetahuan melalui argumentasi dapat membantu peserta didik dalam meningkatkan pemahaman ilmu alam.

Argumentasi ilmiah melibatkan penalaran ilmiah yang digunakan untuk menarik kesimpulan dari informasi yang tersedia dan melibatkan keterampilan berpikir kritis dalam membuat suatu pernyataan berdasarkan fakta (Pallant dan Lee, 2014). Heng, Surif, dan Seng (2014) menyatakan argumentasi ilmiah memainkan peran penting dalam menanamkan konsep-konsep ilmiah pada peserta

didik yang merupakan inti dari kemampuan penalaran dan prestasi akademik. Argumentasi ilmiah dapat digunakan untuk meningkatkan pemahaman peserta didik tentang konsep-konsep ilmiah.

Analisis kualitas argumentasi dapat dilakukan dengan menggunakan metode yang didasarkan pada model argumentasi Toulmin (1958). Menurut model Toulmin, argumentasi yang diungkapkan oleh subyek penelitian akan digolongkan ke dalam 
enam komponen argumentasi, yaitu (1) Claim; (2) Data; (3) Warrant; (4) Backing; (5) Qualifier, dan (6) Rebuttal. Jenis argumentasi tertulis tidak memberikan kesempatan bagi peserta didik untuk mengajukan rebuttal karena peserta didik tidak memiliki akses terhadap argumen peserta didik lain (Cetin, 2014). Pola argumentasi Toulmin disajikan pada Gambar 1.

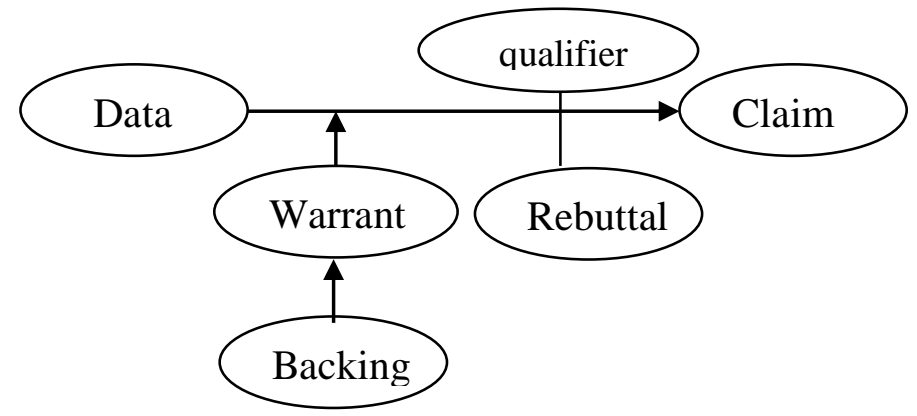

Gambar 1. Pola Argumentasi Toulmin (Toulmin, 1958)

Salah satu materi pelajaran kimia di kelas $\mathrm{X}$ yang membutuhkan banyak argumentasi adalah materi ikatan kimia. Hal ini karena peserta didik tidak hanya dituntut untuk memahami ikatan kimia yang terbentuk akibat sifat logam dan mempengaruhi terjadinya ikatan kimia. Penelitian terdahulu tentang materi ikatan non logam suatu unsur, tetapi peserta didik juga dituntut agar dapat menghubungkan data berupa informasi, fakta, atau hasil pengamatan yang kimia yang dilakukan oleh Rusdiana (2010:52-53) tentang kesulitan belajar dan pemahaman konsep peserta didik kelas X SMA Negeri 6 Malang materi ikatan kimia dengan hasil: (a) Sebagian besar peserta didik mengalami kesulitan pada konsep ikatan ion $(63,66 \%)$ dan pemahaman dikatakan tidak baik (36,81\%); (b) Sebagian besar peserta didik mengalami kesulitan pada konsep ikatan kovalen tunggal, rangkap dua dan rangkap tiga (68,66\%) dan pemahaman dikatakan tidak pada konsep sifat-sifat kepolaran senyawa $(27,62 \%)$ dan hubungannya dengan keelektronegatifan (43,28\%), dan penelitian yang dilakukan oleh Hermanto (2012:114-115) tentang identifikasi kesulitan peserta didik kelas X SMA Negeri 1 Purwosari dalam memahami materi ikatan kimia dengan hasil: (a) Persentase peserta didik yang mengalami kesulitan pada ikatan ion cukup besar (55,6\%); (b) Persentase peserta didik yang mengalami kesulitan pada ikatan kovalen sedikit (39,9\%); dan (c) Persentase peserta didik yang mengalami kesulitan pada senyawa kovalen polar dan non polar besar (64,9\%). Pada penelitian tersebut hanya dilakukan untuk mengetahui kesulitan dan pemahaman peserta didik SMA terhadap materi ikatan kimia tanpa melakukan penelitian untuk peserta didik MA dan mahasiswa perguruan tinggi. Sehingga tujuan penelitian ini adalah menganalisis kemampuan berargumentasi ilmiah materi ikatan kimia peserta didik SMA, MAN, dan Perguruan Tinggi.

\section{METODE}

Rancangan penelitian yang dipilih adalah rancangan penelitian deskriptif dengan pendekatan kualitatif. Penelitian deskriptif bertujuan untuk mendeskripsikan suatu fenomena sebagaimana adanya pada waktu penelitian dilakukan (Wiyono, 2007:28). Subyek penelitian dalam penelitian ini adalah peserta didik kelas X MIA 1 SMA Negeri 
1 Lawang sebanyak 32 peserta didik, X MIA 3 MA Negeri 1 Malang, dan Universitas Negeri Malang (UM) Prodi Pendidika Kimia Offering A Semester dua angkatan 2016 sebanyak 31 mahasiswa. Pada penelitian ini, subyek tidak diberikan perlakuan karena perlakuan sudah terjadi sebelumnya, yaitu kegiatan belajar mengajar materi ikatan kimia. Instrumen penelitian berupa 3 butir soal esai kemampuan berargumentasi dan pedoman wawancara peserta didik. Analisis mengenai kemampuan berargumentasi ilmiah peserta didik menggunakan sistem kategori kompleksitas argumentasi modifikasi dari Cetin (2014). Analisis mengenai pengaruh jenjang pendidikan terhadap kemampuan berargumentasi ilmiah peserta didik menggunakan teknik Mann-Wbitney One Tail. Analisis tentang faktor-faktor yang mempengaruhi kemampuan berargumentasi ilmiah peserta didik didasarkan pada hasil wawancara. Hasil wawancara dilakukan pengecekan keabsahan data dengan cara triangulasi metode/teknik dan menggunakan bahan referensi.

\section{PEMBAHASAN}

\section{A. Kemampuan Berargumentasi Ilmiah Peserta Didik SMA Negeri 1 Lawang}

Persentase peserta didik SMA Negeri 1 Lawang dalam menyampaikan argumentasi pada masing-masing butir soal disajikan dalam Tabel 1. Berdasarkan Tabel 1 menunjukkan bahwa kemampuan berargumentasi ilmiah peserta didik SMA Negeri 1 Lawang paling tinggi diperoleh pada level 2a sebesar 49,31\% dengan kriteria cukup. Kategori tersebut mendominasi tingkat argumentasi peserta didik SMA Negeri 1 Lawang. Berdasarkan hasil analisis jawaban peserta didik SMA Negeri 1 Lawang, sebagian besar peserta didik menggunakan data yang tidak disertai dengan penjelasan ilmiah untuk mendukung claim mereka. Hal ini menunjukkan peserta didik hanya menghafal sifat-sifat mendasar dari ikatan ion, ikatan kovalen, dan kepolaran molekul. Selain itu, peserta didik kurang memahami penjelasan ilmiah dari sifat-sifat tersebut. Hal ini sesuai dengan hasil wawancara dengan peserta didik yang menyatakan bahwa materi ikatan kimia termasuk materi yang cukup sulit, karena materinya rumit, banyak hafalan, dan banyak konsep yang harus dipahami. Peserta didik mengalami kebingungan apabila terlalu banyak variasi soal, karena peserta didik belum memahami materi secara mendalam.

\section{B. Kemampuan Berargumentasi Ilmiah Peserta Didik MA Negeri 1 Malang}

Persentase peserta didik MA Negeri 1 Malang dalam menyampaikan argumentasi pada masing-masing butir soal disajikan dalam Tabel 2. Berdasarkan Tabel 2 menunjukkan bahwa kemampuan berargumentasi ilmiah peserta didik MA Negeri 1 Malang paling tinggi diperoleh pada level 2a sebesar 47,91\% dengan kriteria cukup. Kategori tersebut mendominasi tingkat argumentasi peserta didik MA Negeri 1 Malang. Berdasarkan hasil analisis jawaban peserta didik MA Negeri 1 Malang bahwa peserta didik belum mampu memberikan penjelasan ilmiah yang dapat mendukung claim mereka. Berdasarkan hasil wawancara dengan peserta didik, beberapa peserta didik mengalami kesulitan untuk memahami materi ikatan kimia. Hal ini disebabkan karena peserta didik kurang memahami sifat-sifat mendasar dari ikatan ion, ikatan kovalen, dan kepolaran senyawa. Selain itu, peserta didik merasa materi yang dipelajari sangat banyak, sehingga 
dapat berpengaruh terhadap pemahaman mereka. Hasil wawancara dengan peserta didik MA Negeri 1 Malang menyatakan bahwa peserta didik mengalami kesulitan untuk memahami materi ikatan kimia. Selain itu, peserta didik merasa materi yang dipelajari sangat banyak, sehingga dapat berpengaruh terhadap pemahaman mereka. Hasil penelitian ini didukung dengan penelitian terdahulu yang serupa, Bell dan Linn (2000) menyimpulkan bahwa penjelasan peserta didik umumnya hanya menggunakan warrant untuk mendukung claimnya bukan dengan backing. Beberapa peserta didik juga ada yang mengggunakan data untuk mendukung claimnya.

Tabel 1 Persentase Peserta Didik SMA Negeri 1 Lawang dalam Menyampaikan Argumentasi pada Masing-masing Butir Soal

\begin{tabular}{|c|c|c|c|c|c|}
\hline No. & Indikator & $\begin{array}{l}\text { Level } \\
\text { argumentasi }\end{array}$ & $\begin{array}{l}\text { Jumlah } \\
\text { peserta } \\
\text { didik }\end{array}$ & $\begin{array}{l}\text { \% Peserta didik } \\
\text { dalam } \\
\text { menyampaikan } \\
\text { argumentasi }\end{array}$ & Kriteria \\
\hline \multirow[t]{14}{*}{1.} & \multirow{14}{*}{$\begin{array}{l}\text { Diberikan beberapa senyawa, } \\
\text { peserta didik dapat menjelaskan } \\
\text { ikatan ion pada senyawa tersebut } \\
\text { berdasarkan titik didih dan titik } \\
\text { lelehnya. }\end{array}$} & - & 9 & $28,12 \%$ & Sedikit \\
\hline & & 1 & 3 & $8,33 \%$ & Sangat sedikit \\
\hline & & $2 \mathrm{a}$ & 10 & $27,78 \%$ & Sedikit \\
\hline & & $2 \mathrm{~b}$ & 4 & $11,11 \%$ & Sangat sedikit \\
\hline & & $2 c$ & 4 & $11,11 \%$ & Sangat sedikit \\
\hline & & $3 a$ & 2 & $5,56 \%$ & Sangat sedikit \\
\hline & & $3 \mathrm{~b}$ & 0 & $0 \%$ & - \\
\hline & & $3 c$ & 0 & $0 \%$ & - \\
\hline & & $3 d$ & 0 & $0 \%$ & - \\
\hline & & $3 e$ & 0 & $0 \%$ & - \\
\hline & & $3 f$ & 0 & $0 \%$ & - \\
\hline & & $4 a$ & 0 & $0 \%$ & - \\
\hline & & $4 b$ & 0 & $0 \%$ & - \\
\hline & & $4 c$ & 0 & $0 \%$ & - \\
\hline \multirow[t]{14}{*}{2.} & \multirow{14}{*}{$\begin{array}{l}\text { Diberikan beberapa senyawa, } \\
\text { peserta didik dapat menjelaskan } \\
\text { ikatan kovalen pada senyawa } \\
\text { tersebut berdasarkan titik leleh } \\
\text { dan titik didihnya. }\end{array}$} & - & 0 & $0 \%$ & - \\
\hline & & 1 & 5 & $15,62 \%$ & Sangat sedikit \\
\hline & & $2 \mathrm{a}$ & 14 & $38,89 \%$ & Sedikit \\
\hline & & $2 \mathrm{~b}$ & 9 & $28,12 \%$ & Sedikit \\
\hline & & $2 c$ & 4 & $11,11 \%$ & Sangat sedikit \\
\hline & & $3 a$ & 0 & $0 \%$ & - \\
\hline & & $3 b$ & 0 & $0 \%$ & - \\
\hline & & $3 c$ & 0 & $0 \%$ & - \\
\hline & & $3 d$ & 0 & $0 \%$ & - \\
\hline & & $3 e$ & 0 & $0 \%$ & - \\
\hline & & $3 \mathrm{f}$ & 0 & $0 \%$ & - \\
\hline & & $4 a$ & 0 & $0 \%$ & - \\
\hline & & $4 b$ & 0 & $0 \%$ & - \\
\hline & & $4 c$ & 0 & $0 \%$ & - \\
\hline \multirow[t]{11}{*}{3.} & \multirow{11}{*}{$\begin{array}{l}\text { Diberikan beberapa senyawa, } \\
\text { peserta didik dapat menjelaskan } \\
\text { ikatan kovalen polar pada } \\
\text { senyawa tersebut berdasarkan } \\
\text { harga momen dipol. }\end{array}$} & - & 0 & $0 \%$ & - \\
\hline & & 1 & 5 & $15,62 \%$ & Sangat sedikit \\
\hline & & $2 \mathrm{a}$ & 26 & $81,25 \%$ & Sangat banyak \\
\hline & & $2 \mathrm{~b}$ & 1 & $2,77 \%$ & Sangat sedikit \\
\hline & & $2 c$ & 0 & $0 \%$ & - \\
\hline & & $3 a$ & 0 & $0 \%$ & - \\
\hline & & $3 b$ & 0 & $0 \%$ & - \\
\hline & & $3 c$ & 0 & $0 \%$ & - \\
\hline & & $3 d$ & 0 & $0 \%$ & - \\
\hline & & $3 e$ & 0 & $0 \%$ & - \\
\hline & & $3 f$ & 0 & $0 \%$ & - \\
\hline
\end{tabular}




\begin{tabular}{lllll}
\hline \multirow{2}{*}{ No. Indikator } & $\begin{array}{l}\text { Level } \\
\text { argumentasi }\end{array}$ & $\begin{array}{l}\text { Jumlah } \\
\text { peserta } \\
\text { didik }\end{array}$ & $\begin{array}{l}\% \text { Peserta didik } \\
\text { dalam } \\
\text { menyampaikan } \\
\text { argumentasi }\end{array}$ & Kriteria \\
\hline & $4 \mathrm{a}$ & 0 & $0 \%$ & - \\
& $4 \mathrm{~b}$ & 0 & $0 \%$ & - \\
\hline Rata-rata keseluruhan & $4 \mathrm{c}$ & 0 & $0 \%$ & - \\
& - & & $28,12 \%$ & Sedikit \\
& 1 & $13,19 \%$ & Sangat sedikit \\
& $2 \mathrm{a}$ & & $49,31 \%$ & Cukup \\
& $2 \mathrm{~b}$ & & $14,00 \%$ & Sangat sedikit \\
& $2 \mathrm{c}$ & & $7,40 \%$ & Sangat sedikit \\
& $3 \mathrm{a}$ & & $1,85 \%$ & sangat sedikit \\
\hline
\end{tabular}

Tabel 2 Persentase Peserta Didik MA Negeri 1 Malang dalam Menyampaikan Argumentasi pada Masing-masing Butir Soal

\begin{tabular}{|c|c|c|c|c|c|}
\hline No. & Indikator & $\begin{array}{c}\text { Level } \\
\text { argumentasi }\end{array}$ & $\begin{array}{l}\text { Jumlah } \\
\text { peserta } \\
\text { didik }\end{array}$ & $\begin{array}{l}\% \text { Peserta didik } \\
\text { dalam } \\
\text { menyampaikan } \\
\text { argumentasi }\end{array}$ & Kriteria \\
\hline \multirow[t]{14}{*}{1.} & Diberikan beberapa & - & 2 & $6,25 \%$ & Sangat sedikit \\
\hline & senyawa, peserta didik & 1 & 11 & $34,37 \%$ & Sedikit \\
\hline & dapat menjelaskan ikatan & $2 \mathrm{a}$ & 16 & $50 \%$ & Cukup \\
\hline & ion pada senyawa & $2 \mathrm{~b}$ & 2 & $6,25 \%$ & Sangat sedikit \\
\hline & tersebut berdasarkan & $2 \mathrm{c}$ & 0 & $0 \%$ & - \\
\hline & titik didih dan titik & $3 a$ & 1 & $3,13 \%$ & Sangat sedikit \\
\hline & lelehnya. & $3 \mathrm{~b}$ & 0 & $0 \%$ & - \\
\hline & & $3 c$ & 0 & $0 \%$ & - \\
\hline & & $3 \mathrm{~d}$ & 0 & $0 \%$ & - \\
\hline & & $3 e$ & 0 & $0 \%$ & - \\
\hline & & $3 \mathrm{f}$ & 0 & $0 \%$ & - \\
\hline & & $4 \mathrm{a}$ & 0 & $0 \%$ & - \\
\hline & & $4 \mathrm{~b}$ & 0 & $0 \%$ & - \\
\hline & & $4 \mathrm{c}$ & 0 & $0 \%$ & - \\
\hline \multirow[t]{14}{*}{2.} & Diberikan beberapa & - & 1 & $3,13 \%$ & Sangat sedikit \\
\hline & senyawa, peserta didik & 1 & 5 & $15,62 \%$ & Sangat sedikit \\
\hline & dapat menjelaskan ikatan & $2 \mathrm{a}$ & 13 & $40,62 \%$ & Cukup \\
\hline & kovalen pada senyawa & $2 \mathrm{~b}$ & 7 & $21,88 \%$ & Sedikit \\
\hline & tersebut berdasarkan & $2 \mathrm{c}$ & 6 & $18,75 \%$ & Sangat sedikit \\
\hline & titik leleh dan titik & $3 a$ & 0 & $0 \%$ & - \\
\hline & didihnya. & $3 \mathrm{~b}$ & 0 & $0 \%$ & - \\
\hline & & $3 c$ & 0 & $0 \%$ & - \\
\hline & & $3 \mathrm{~d}$ & 0 & $0 \%$ & - \\
\hline & & $3 e$ & 0 & $0 \%$ & - \\
\hline & & $3 \mathrm{f}$ & 0 & $0 \%$ & - \\
\hline & & $4 \mathrm{a}$ & 0 & $0 \%$ & - \\
\hline & & $4 \mathrm{~b}$ & 0 & $0 \%$ & - \\
\hline & & $4 \mathrm{c}$ & 0 & $0 \%$ & - \\
\hline \multirow[t]{5}{*}{3.} & Diberikan beberapa & - & 0 & $0 \%$ & - \\
\hline & senyawa, peserta didik & 1 & 15 & $46,88 \%$ & Cukup \\
\hline & dapat menjelaskan ikatan & $2 \mathrm{a}$ & 17 & $53,12 \%$ & Cukup \\
\hline & kovalen polar pada & $2 \mathrm{~b}$ & 0 & $0 \%$ & - \\
\hline & senyawa tersebut & $2 c$ & 0 & $0 \%$ & - \\
\hline
\end{tabular}




\begin{tabular}{|c|c|c|c|c|}
\hline Indikator & $\begin{array}{c}\text { Level } \\
\text { argumentasi }\end{array}$ & $\begin{array}{c}\text { Jumlah } \\
\text { peserta } \\
\text { didik }\end{array}$ & $\begin{array}{l}\% \text { Peserta didik } \\
\text { dalam } \\
\text { menyampaikan } \\
\text { argumentasi }\end{array}$ & Kriteria \\
\hline berdasarkan harga & $3 a$ & 0 & $0 \%$ & - \\
\hline \multirow[t]{8}{*}{ momen dipol. } & $3 \mathrm{~b}$ & 0 & $0 \%$ & - \\
\hline & $3 c$ & 0 & $0 \%$ & - \\
\hline & $3 d$ & 0 & $0 \%$ & - \\
\hline & $3 e$ & 0 & $0 \%$ & - \\
\hline & $3 \mathrm{f}$ & 0 & $0 \%$ & - \\
\hline & $4 \mathrm{a}$ & 0 & $0 \%$ & - \\
\hline & $4 \mathrm{~b}$ & 0 & $0 \%$ & - \\
\hline & $4 c$ & 0 & $0 \%$ & - \\
\hline \multirow[t]{6}{*}{ Rata-rata keseluruhan } & - & & $3,13 \%$ & Sangat sedikit \\
\hline & 1 & & $32,29 \%$ & Sedikit \\
\hline & $2 \mathrm{a}$ & & $47,91 \%$ & Cukup \\
\hline & $2 \mathrm{~b}$ & & $9,38 \%$ & Sangat sedikit \\
\hline & $2 c$ & & $6,25 \%$ & Sangat sedikit \\
\hline & $3 \mathrm{a}$ & & $1,04 \%$ & Sangat sedikit \\
\hline
\end{tabular}

\section{Kemampuan Berargumentasi Ilmiah Mahasiswa UM Prodi Pendidikan Kimia Semester Dua Angkatan 2016}

Persentase semester 2 Angkatan 2016 dalam menyampaikan argumentasi pada masingmasing butir soal disajikan dalam Tabel 3.

Tabel 3 Persentase Mahasiswa Universitas Negeri Malang Prodi Pendidikan Kimia Offering A Semester Dua Angkatan 2016 dalam Menyampaikan Argumentasi pada Masing-masing Butir Soal

\begin{tabular}{|c|c|c|c|c|c|}
\hline No. & Indikator & $\begin{array}{l}\text { Level } \\
\text { argumen } \\
\text { tasi }\end{array}$ & $\begin{array}{l}\text { Jumlah } \\
\text { peserta } \\
\text { didik }\end{array}$ & $\begin{array}{l}\% \text { Peserta didik dalam } \\
\text { menyampaikan } \\
\text { argumentasi }\end{array}$ & Kriteria \\
\hline \multirow[t]{14}{*}{1.} & \multirow{14}{*}{$\begin{array}{l}\text { Diberikan beberapa senyawa, } \\
\text { peserta didik dapat menjelaskan } \\
\text { ikatan ion pada senyawa } \\
\text { tersebut berdasarkan titik didih } \\
\text { dan titik lelehnya. }\end{array}$} & - & 6 & $19,35 \%$ & Sangat sedikit \\
\hline & & 1 & 0 & $0 \%$ & - \\
\hline & & $2 \mathrm{a}$ & 13 & $41,94 \%$ & Cukup \\
\hline & & $2 b$ & 0 & $0 \%$ & - \\
\hline & & $2 c$ & 7 & $22,58 \%$ & Sedikit \\
\hline & & $3 a$ & 4 & $12,90 \%$ & Sangat sedikit \\
\hline & & $3 b$ & 0 & $0 \%$ & - \\
\hline & & $3 c$ & 0 & $0 \%$ & - \\
\hline & & $3 d$ & 0 & $0 \%$ & - \\
\hline & & $3 e$ & 0 & $0 \%$ & - \\
\hline & & $3 f$ & 0 & $0 \%$ & - \\
\hline & & $4 a$ & 0 & $0 \%$ & - \\
\hline & & $4 \mathrm{~b}$ & 0 & $0 \%$ & - \\
\hline & & $4 c$ & 1 & $3,23 \%$ & Sangat sedikit \\
\hline \multirow[t]{8}{*}{2.} & \multirow{8}{*}{$\begin{array}{l}\text { Diberikan beberapa senyawa, } \\
\text { peserta didik dapat menjelaskan } \\
\text { ikatan kovalen pada senyawa } \\
\text { tersebut berdasarkan titik leleh } \\
\text { dan titik didihnya. }\end{array}$} & - & 0 & $0 \%$ & - \\
\hline & & 1 & 0 & $0 \%$ & - \\
\hline & & $2 \mathrm{a}$ & 16 & $51,61 \%$ & Cukup \\
\hline & & $2 \mathrm{~b}$ & 2 & $6,45 \%$ & Sangat sedikit \\
\hline & & $2 c$ & 8 & $25,81 \%$ & Sedikit \\
\hline & & $3 a$ & 5 & $16,13 \%$ & Sangat sedikit \\
\hline & & $3 b$ & 0 & $0 \%$ & - \\
\hline & & $3 c$ & 0 & $0 \%$ & - \\
\hline
\end{tabular}




\begin{tabular}{lllll}
\hline \multirow{2}{*}{ No. Indikator } & $\begin{array}{l}\text { Level } \\
\text { argumen } \\
\text { tasi }\end{array}$ & $\begin{array}{l}\text { Jumlah } \\
\text { peserta } \\
\text { didik }\end{array}$ & $\begin{array}{l}\% \text { Peserta didik dalam } \\
\text { menyampaikan } \\
\text { argumentasi }\end{array}$ & Kriteria \\
\hline & $3 \mathrm{~d}$ & 0 & $0 \%$ & - \\
& $3 \mathrm{e}$ & 0 & $0 \%$ & - \\
& $3 \mathrm{f}$ & 0 & $0 \%$ & - \\
& $4 \mathrm{a}$ & 0 & $0 \%$ & - \\
& $4 \mathrm{~b}$ & 0 & $0 \%$ & - \\
\hline 3. & 4c & 0 & $0 \%$ & Sangat sedikit \\
piberikan beberapa senyawa, & - & 3 & $9,68 \%$ & Sangat sedikit \\
peserta didik dapat menjelaskan & 1 & 6 & $19,35 \%$ & Banyak \\
senyawa tersebut berdasarkan & $2 \mathrm{a}$ & 21 & $67,74 \%$ & - \\
harga momen dipol. & $2 \mathrm{~b}$ & 0 & $0 \%$ & Sangat sedikit \\
& $2 \mathrm{c}$ & 1 & $3,23 \%$ & - \\
& $3 \mathrm{a}$ & 0 & $0 \%$ & - \\
& $3 \mathrm{~b}$ & 0 & $0 \%$ & - \\
& $3 \mathrm{c}$ & 0 & $0 \%$ & - \\
& $3 \mathrm{~d}$ & 0 & $0 \%$ & - \\
& $3 \mathrm{e}$ & 0 & $0 \%$ & - \\
& $3 \mathrm{f}$ & 0 & $0 \%$ & - \\
\hline Rata-rata keseluruhan & $4 \mathrm{a}$ & 0 & $0 \%$ & - \\
\hline & $4 \mathrm{~b}$ & 0 & $0 \%$ & Sangat sedikit \\
& $4 \mathrm{c}$ & 0 & $0 \%$ & Sangat sedikit \\
& - & & $9,68 \%$ & Cukup \\
& 1 & & $6,45 \%$ & Sangat sedikit \\
& $2 \mathrm{a}$ & & $53,76 \%$ & Sangat sedikit \\
& $2 \mathrm{~b}$ & & $2,15 \%$ & Sangat sedikit \\
& $2 \mathrm{c}$ & & $17,20 \%$ & Sangat sedikit \\
\hline
\end{tabular}

Tabel 3 menunjukkan rata-rata persentase keseluruhan kemampuan berargumentasi ilmiah mahasiswa UM Prodi Pendidikan Kimia semester dua angkatan 2016 paling tinggi diperoleh pada level 2a sebesar 53,76\% dengan kriteria cukup. Kategori tersebut mendominasi tingkat argumentasi mahasiswa UM Prodi Pendidikan Kimia semester dua angkatan 2016. Berdasarkan hasil analisis jawaban mahasiswa, ada beberapa mahasiswa yang mampu membuat penjelasan ilmiah yang didasarkan pada claim dengan data, warrant dengan backing dan ada satu mahasiswa yang mampu mencapai komponen qualifier. Hasil penelitian ini didukung dengan penelitian terdahulu oleh Bekiroglu dan Eskin (2012) menyatakan mereka yang mampu mencapai komponen argumentasi lebih banyak yang menghasilkan claim, mempertahankan claim mereka dengan backing dan qualifier jika mereka terbiasa memperdebatkan gagasan yang dimilikinya. Berdasarkan hasil wawancara dengan mahasiswa yang menyatakan bahwa mahasiswa menganggap materi ini cukup sulit. Selain itu, mahasiswa terkadang masih mengalami kesulitan untuk membedakan ikatan ion dan ikatan kovalen.

\section{Hubungan Jenjang Pendidikan terhadap Kemampuan Berargumentasi Ilmiah Peserta Didik}

Analisis dalam penelitian ini untuk mengetahui kemampuan berargumentasi ilmiah jenjang pendidikan mana yang memiliki kemampuan berargumentasi lebih tinggi menggunakan uji Mann-Whitney One Tail dengan bantuan SPSS 21 for Windows. Hasil 
uji Mann-Whitney One Tail menunjukkan bahwa rata-rata kemampuan berargumentasi ilmiah paling tinggi adalah mahasiswa UM Prodi Pendidikan Kimia semester dua angkatan 2016, selanjutnya peserta didik SMA Negeri 1 Lawang, dan yang terakhir peserta didik MA Negeri 1 Malang.

Seluruh jenjang pendidikan tersebut didominasi dengan level 2a. Level 2a dengan persentase tertinggi yaitu mahasiswa UM Prodi Pendidikan Kimia semester dua angkatan 2016 sebesar 53,76\% diikuti peserta didik SMA Negeri 1 Lawang sebesar 49,31\% dan MA Negeri 1 Malang sebesar 47,91\%. Hasil analisis kemampuan berargumentasi ilmiah mahasiswa UM Prodi Pendidikan Kimia Offering A semester dua angkatan 2016 dapat mencapai level tertinggi (level 4c). Hal ini dimungkinkan pemahaman mahasiswa lebih mendalam dibandingkan peserta didik di SMA, sehingga mahasiswa mampu mengaplikasikan teori-teori dalam menyelesaikan suatu permasalahan.

\section{E. Faktor-faktor yang Mempengaruhi Kemampuan Berargumentasi Ilmiah Peserta Didik}

Faktor-faktor yang mempengaruhi kemampuan berargumentasi ilmiah peserta didik adalah pemahaman peserta didik terhadap materi ikatan kimia dan keterlibatan peserta didik dalam kegiatan argumentasi selama proses pembelajaran. Pemahaman peserta didik dikatakan baik apabila peserta didik mampu menjawab pertanyaan dengan berbagai tipe soal. Keterlibatan peserta didik yang kurang maksimal selama proses pembelajaran, dimungkinkan dapat berpengaruh terhadap kemampuan berargumentasi ilmiah peserta didik. Hal ini disebabkan karena peserta didik kurang terlatih untuk berargumentasi secara ilmiah.

\section{KESIMPULAN}

Berdasarkan hasil penelitian dan pembahasan yang telah diuraikan sebelumnya, maka dapat disimpulkan bahwa: (1) Kemampuan berargumentasi ilmiah materi ikatan kimia peserta didik SMA Negeri 1 Lawang didominasi level 2a dengan persentase sebesar 49,31\% diikuti dengan peserta didik yang belum tepat dalam menjawab sebesar $28,12 \%$, kemudian level $2 \mathrm{~b}$ sebesar 14,00\%, level 1 sebesar 13,19\%, level 2c sebesar $7,40 \%$, dan level 3 a sebesar 1,85\%; (2) Kemampuan berargumentasi ilmiah materi ikatan kimia peserta didik MA Negeri 1 Malang didominasi level 2a dengan persentase sebesar 47,91\% diikuti level 1 sebesar 32,29\%, level 2b sebesar 9,38\%, level 2c sebesar $6,25 \%$, peserta didik yang belum tepat dalam menjawab sebesar $3,13 \%$, dan level 3 a sebesar 1,04\%; (3) Kemampuan berargumentasi ilmiah mahasiswa UM Prodi Pendidikan Kimia semester dua angkatan 2016 didominasi level 2a dengan persentase sebesar 53,76\% diikuti level 3a sebesar 18,28\%, level 2c sebesar 17,20\%, peserta didik yang belum tepat dalam menjawab sebesar 9,68\%, level 1 sebesar $6,45 \%$, level $2 \mathrm{~b}$ sebesar 2,15\%, dan level 4c sebesar 1,08\%; (4) Tidak ada perbedaan kemampuan berargumentasi ilmiah materi ikatan kimia antara SMA Negeri 1 Lawang dengan MA Negeri 1 Malang, SMA Negeri 1 Lawang dengan UM Prodi Pendidikan Kimia semester dua angkatan 2016, dan ada perbedaan antara MA Negeri 1 Malang dengan UM Prodi Pendidikan Kimia semester dua angkatan 2016; (5) Faktor-faktor yang mempengaruhi kemampuan berargumentasi ilmiah peserta didik adalah pemahaman peserta didik 
terhadap materi ikatan kimia dan keterlibatan peserta didik dalam kegiatan argumentasi selama proses pembelajaran.

Berdasarkan hasil penelitian yang diperoleh, maka dapat dipaparkan saran-saran sebagai berikut: (1) Perlu adanya penekanan kemampuan berargumentasi ilmiah dalam pembelajaran kimia pada materi ikatan kimia. Dengan demikian, peserta didik mampu memahami materi ikatan kimia secara mendalam; (2) Kemampuan berargumentasi perlu dikembangkan agar peserta didik dapat berpartisipasi aktif dalam proses diskusi ilmiah. Kemampuan berargumentasi dikembangkan melalui serangkaian pembelajaran dalam pendidikan; (3) Faktor-faktor yang berpengaruh terhadap kemampuan berargumentasi yang ditemukan dalam penelitian belum diuji secara statistik sehingga peneliti lain perlu untuk meneliti lebih lanjut; (4) Perlu dilakukan penelitian lebih lanjut mengenai metode pembelajaran yang dapat meningkatkan kemampuan berargumentasi ilmiah pada materi ikatan kimia.

\section{DAFTAR RUJUKAN}

Aydeniz, M. \& Ozdilek, Z. 2015. Assessing Pre-Service Science Teachers' Understanding of Scientific Argumentation: What Do They Know About Argumentation After Four Years of College Science?. Science Education International, (Online), 26 (2): 217-239, (files.eric.ed.gov/fulltext/EJ1064033.pdf), diakses 2 Januari 2017.

Bekiroglu, R.O. \& Eskin, H. 2012. Examination of the Relationship Between Engagement in Scientific Argumentation and Conceptual Knowledge. International Journal of Science and Mathematics Education, (Online), 10: 1415-1443, (link.springer.com/content/pdf/10.1007/s10763-012-9346-z.pdf), diakses 2 Januari 2017.

Bell, P. \& Linn, M. C. 2000. Scientific Argument as Learning Artifact, Designning for Learning from The Web With KIE. International Journal of Science Education, (Online), 22 (8): 797-817, (www.designbasedresearch.org/reppubs/bell-Linn.pdf), diakses 15 Mei 2017.

Cetin, P.S. 2014. Explicit Argumentation Instruction to Facilitate Conceptual Understanding and Argumentation Skills. Research in Science \& Technological Education, (Online), 32 (1): 1-20, (http://dx.doi.org/10.1080/02635143.2013.850071), diakses 2 Januari 2017.

Effendy. 2016. Ilmu Kimia untuk Siswa SMA dan MA Kelas X. Malang: Indonesian Academic Publishing.

Faika, S. \& Side, S. 2011. Analisis Kesulitan Mahasiswa dalam Perkuliahan dan Praktikum Kimia Dasar di Jurusan Kimia FMIPA Universitas Negeri Makassar. Jurnal Chemical, (Online), 12 (2): 18-26, (ojs.unm.ac.id/index.php/chemica/article/view/497), diakses 2 Januari 2017.

Heng, L.L., Surif, J., \& Seng, C.H. 2014. Individual Versus Group Argumentation: Student's Performance in a Malaysian Context. International Education Studies, (Online), 7 (7): 109-124, (files.eric.ed.gov/fulltext/EJ1070390.pdf), diakses 3 Januari 2017.

Hermanto, M. 2012. Identifikasi Kesulitan dalam Memahami Materi Ikatan Kimia Pada Siswa Kelas X SMA N 1 Purwosari. Skripsi tidak dipublikasikan. Malang: Jurusan Pendidikan Kimia FMIPA Universitas Negeri Malang.

Holme, T., Luxford, C.J. \& Brandriet, A. 2015. Defining Conceptual Understanding in General Chemistry. Journal of Chemical Education, (Online), 92: 1477-1483.

Kuhn, D. 2010. Teaching and Learning Science as Argument. Science Education, (Online), 94: 810-824.

Pallant, A.R. \& Lee, H.S. 2014. Constructing Scientific Arguments Using Evidence from Dynamic Computational Climate Models. Journal of Science Education and Technology, 24:378395. 
Pratiwi, Y.N. 2016. Pengaruh Sociosientific Issue (SSI) sebagai Konteks Pembelajaran Kooperatif pada Materi Laju Reaksi terhadap Pemahaman Konsep, Keterampilan Berpikir Kritis dan Keterampilan Berargumentasi Siswa. Tesis. Tidak diterbitkan. Malang: Universitas Negeri Malang.

Rusdiana, I. 2010. Identifikasi Kesulitan Belajar dan Pemahaman Konsep Siswa dalam Materi Ikatan Kimia Kelas X Semester 1 SMA Negei 6 Malang. Skripsi tidak dipublikasikan. Malang: Jurusan Pendidikan Kimia FMIPA Universitas Negeri Malang.

Solfarina. 2012. Peningkatan Pemahaman Konsep Ikatan Kimia Mahasiswa Calon Guru melalui Pembelajaran Berbasis E-Learning. Jurnal Chemica, (Online), 13 (2): 1-10, (ojs.unm.ac.id/index.php/chemica/article/view/619), diakses 4 Januari 2017.

Toulmin, S. 1958. The uses of argument. International Journal of Science Education, (Online), 34 (130): 244-245,

Wiyono, B.B. 2007. Metode Penelitian (Pendekatan Kuantitatif, Kualitatif, dan Action Research). Malang: Fakultas Ilmu Pendidikan Universitas Negeri Malang. 